\title{
Polynucleotide Sequence Relatedness in Edwardsiella tarda
}

\author{
DON J. BRENNER, G. R. FANNING, and A. G. STEIGERWALT
}

Division of Biochemistry, Walter Reed Army Institute of Research, Washington, D.C. 20012

\begin{abstract}
Relatedness among strains of Edwardsiella tarda was determined by using interspecific deoxyribonucleic acid reassociation followed by chromatography on hydroxyapatite. Relatedness was also assessed among $E$. tarda and representatives from all other established genera of the family Enterobacteriaceae. Twenty strains of $E$. tarda from five countries and 11 states, isolated from diseased human, normal human, and invertebrate sources, all formed one highly related hybridization group. E. tarda exhibited 20 to $29 \%$ relatedness to other enterobacteria. These data are consistent with the previous designation of a separate tribe, Edwardsielleae, for a single genus (Edwardsiella) and species ( $E$. tarda).
\end{abstract}

The most recently described tribe of the family Enterobacteriaceae is Edwardsielleae (8). Edwardsielleae contains one genus, Edwardsiella Ewing and $\mathrm{McWhorter}$, with a single species, $E$. tarda (8). This organism was first recognized in 1959 in Japan (11) and in the United States (8). Sakazaki (11) proposed the term Asakusa group for these organisms. King and Adler (9) independently isolated similar organisms and termed them the Bartholomew group. Ewing and his colleagues (8) named their organisms Edwardsiella tarda. The biochemical characteristics of all of these organisms are nearly identical $(7,11)$.

Ewing and colleagues (7) have identified 49 $O$ antigen groups, 36 flagellar antigens, and 144 serotypes in 255 strains. In addition to antigenic heterogeneity, $E$. tarda strains show great diversity in geographical distribution and in source of isolation $(7,11)$. In humans, $E$. tarda has been isolated from wounds, urine, blood, feces, and spinal fluid (12).

In the present study, deoxyribonucleic acid (DNA) hybridization was used to assess molecular relatedness in a diverse sampling of $E$. tarda strains. DNA relatedness was also determined between $E$. tarda and representatives of all other tribes of Enterobacteriaceae.

\section{MATERIALS AND METHODS}

Bacterial strains. The E. tarda strains employed in this study are listed in Table 1. The Proteus morganii strain was obtained from S. Falkow. Serratia rubidaea 934-72, Red Mouth organism 2396-61, and Citrobacter freundii 4556-71 were obtained from W. H. Ewing. The other organisms studied were described previously $(3,5)$.
Media. Organisms were maintained on meat extract agar. Routine cultivation was carried out in brain heart infusion broth on a dry-air rotary shaker held at $37 \mathrm{C}$, except for pectobacteria and erwiniae, which were grown at 30 and 23 to $25 \mathrm{C}$, respectively. The medium used for labeling Escherichia coli $\mathrm{K}-12$ with ${ }^{32} \mathrm{PO}_{4}$ has been descirbed (1). None of the 20 strains of $E$. tarda used in this study grew on an unsupplemented medium. This finding is in agreement with that of D'Empaire (6), who found 26 strains of $E$. tarda to require cysteine, methionine, and nicotinamide for growth. To label $E$. tarda, the medium was supplemented with $150 \mu \mathrm{g}$ of cysteine and methionine per $\mathrm{ml}$ and $2.2 \mu \mathrm{g}$ of nicotinamide per $\mathrm{ml}(6)$. The specific activity of the labeled DNAs was between $3 \times 10^{5}$ and $1 \times 10^{6}$ counts per min per $\mu \mathrm{g}$.

DNA reassociation. The preparation, purification, and shearing of both labeled and unlabeled DNA to an average single-strand fragment size of $1.2 \times 10^{5}$ daltons has been described $(1,3)$. The validity of the DNA hybridization data presented depends on the sensitivity and completeness of DNA reassociation in free solution and on the ability of hydroxyapatite (HA) to distinguish quantitatively between singlestranded DNA and DNA duplexes.

In all experiments, $0.1 \mu \mathrm{g}$ of sheared, heatdenatured, ${ }^{32} \mathrm{PO}_{4}$-labeled $\mathrm{DNA} / \mathrm{ml}$ was reacted with $150 \mu \mathrm{g}$ of similarly prepared unlabeled DNA per ml. The DNA reassociation reactions were carried out in $0.28 \mathrm{M} \mathrm{PB}$ (phosphate buffer, an equimolar mixture of $\mathrm{NaH}_{2} \mathrm{PO}_{4}$ and $\mathrm{Na}_{2} \mathrm{HPO}_{4}$ ) for $16 \mathrm{~h}$ at either 60 or 75 C. This exposure carried the reaction for unlabeled DNA to $100 \mathrm{C}_{0} t$ 's (DNA concentration $\times$ time units; reference 4), sufficient for almost complete reassociation of labeled with unlabeled DNA. The $C_{0} t$ for labeled DNA is small enough to preclude substantial reassociation of labeled fragments with one another. This is borne out by control reactions in which $0.1 \mu \mathrm{g}$ of labeled DNA per $\mathrm{ml}$ was incubated in the absence of unlabeled DNA. Only 0.5 to $2 \%$ of the labeled DNA bound to the HA as double-stranded DNA.

After incubation, DNA mixtures were diluted to 
TABLE 1. Edwardsiella tarda ${ }^{a}$ strains used

\begin{tabular}{l|l|l|l}
\hline Strain & Place of isolation & \multicolumn{1}{|c}{ Source } & Antigenic formula \\
\hline $1483-59^{b}$ & Kentucky & Human stool & $01483: \mathrm{h} 1$ \\
$4226-59$ & Wisconsin & Head wound & $04226: \mathrm{H} 2$ \\
$3979-60$ & Equador & Diarrhea, child & $03979: \mathrm{H} 3$ \\
$4830-60$ & Illinois & Arm laceration & $04830: \mathrm{H} 5$ \\
$4862-60$ & Maryland & Stool, diarrhea & $04862: \mathrm{H} 6$ \\
$5343-61$ & Virginia & Human stool & $05343: \mathrm{H} 9$ \\
$3882-61$ & Florida & Human stool & $03882: \mathrm{H} 10$ \\
$5497-61^{c}$ & Japan & Reptile & $05497: \mathrm{H} 31$ \\
$6243-61$ & Louisiana & Human & $06243: \mathrm{H} 11$ \\
$3888-64^{c}$ & Japan & Reptile & $03888: \mathrm{H} 10$ \\
$3889-64^{c}$ & Japan & Reptile & $03889: \mathrm{H} 6$ \\
$3893-64^{c}$ & Japan & Human foot & $03893: \mathrm{H} 6$ \\
$5159-63$ & Tennessee & Infant stool & $05159: \mathrm{H} 1$ \\
$1795-62^{d}$ & Indiana & Fatal meningitis, blood, & $01456: \mathrm{H} 1$ \\
$1126-64$ & Missouri & brain, spinal fluid & $05765: \mathrm{H} 12$ \\
$3592-64^{c}$ & & Human & \\
$2995-65$ & Japan & Turtle & $03592: \mathrm{H} 2,31$ \\
$4751-66$ & Maine & Stool, diarrhea & $01956: \mathrm{H} 18$ \\
$4411-68$ & Congo & Australian skink & $04751: \mathrm{H} 2$ \\
$2334-67$ & Florida & Unknown & $04789: \mathrm{H} 2$ \\
\hline
\end{tabular}

${ }^{a}$ All E. tarda strains and their antigenic formulas were obtained from the Center for Disease Control, Atlanta, $\mathrm{Ga}$.

b Type strain of E. tarda.

c Isolated by Sakazaki; members of the Asakusa group.

d Original Bartholomew group strain.

TABLE 2. Relatedness of Edwardsiella tarda strains to Escherichia coli $K-12$

\begin{tabular}{|c|c|c|c|}
\hline Source of unlabeled DNA & $\begin{array}{c}\text { Relative }(\%) \\
\text { bindings, } 60 \mathrm{C}\end{array}$ & $\begin{array}{c}\text { Divergence }(\%),{ }^{a} \\
60 \mathrm{C}\end{array}$ & $\begin{array}{c}\text { Relative (\%) } \\
\text { binding, } 75 \mathrm{C}\end{array}$ \\
\hline Edwardsiella tarda 1795-62 & 21 & 15.7 & 3.9 \\
\hline E. tarda $2334-67$ & 18 & 14.3 & 2.2 \\
\hline E. tarda 5159-63 & 17 & 14.2 & 2.2 \\
\hline E. tarda $1483-59$ & 22 & 10.1 & 9.3 \\
\hline E. tarda $1126-64$ & 19 & 13.7 & 3.4 \\
\hline E. tarda $2995-65$ & 20 & 13.4 & 2.7 \\
\hline E. tarda $4226-59$ & 22 & 13.7 & 2.9 \\
\hline E. tarda $4862-60$ & 24 & 13.3 & 3.7 \\
\hline E. tarda $5497-61$ & 24 & 14.6 & 4.2 \\
\hline E. tarda 4411-68 & 25 & 13.9 & 6.0 \\
\hline E. tarda $3979-60$ & 18 & 15.3 & 5.8 \\
\hline E. tarda 4751-66 & 19 & 13.3 & 6.9 \\
\hline E. tarda $3889-64$ & 20 & 13.0 & 2.4 \\
\hline E. tarda 3893-64 & 18 & 13.1 & 2.5 \\
\hline E. tarda $3888-64$ & 20 & 12.6 & 3.7 \\
\hline E. tarda $4830-60$ & 23 & 11.9 & 6.1 \\
\hline E. tarda 5343-61 & 21 & 13.1 & 2.7 \\
\hline Shigella flexneri 25470 & 84 & 1.0 & 79 \\
\hline Salmonella typhimurium LT2 & 44 & 11.7 & 11 \\
\hline Citrobacter freundii $\mathrm{P} 11-\mathrm{C}$ & 50 & 12.5 & 11 \\
\hline Klebsiella pneumoniae 2 & 38 & 14.2 & 7 \\
\hline Enterobacter cloacae & 35 & 13.1 & 5 \\
\hline Serratia marcescens & 24 & 14.1 & 2.7 \\
\hline Enterobacter hafniae & 21 & 15.8 & 4 \\
\hline Proteus morganii & 17 & 16.7 & 2.5 \\
\hline P. mirabilis & 8 & NT & 1.5 \\
\hline
\end{tabular}

${ }^{a}$ Calculated on the assumption that each $1 \mathrm{C}$ decrease in the $T_{m(e)}$ of a DNA heteroduplex [compared to the $T_{m(e)}$ of a homologous DNA duplex] reflects $1 \%$ unpaired nucleotide bases or divergence (10). $T_{m(e)}$ is the thermal elution midpoint, i.e., that temperature at which $50 \%$ of the DNA bound to hydroxyapatite is eluted. NT, Not tested. 
$0.14 \mathrm{M} \mathrm{PB}$ and applied to HA that was equilibrated in $0.14 \mathrm{M} \mathrm{PB}+0.4 \%$ sodium dodecyl sulfate and held at $60 \mathrm{C}$. Unhybridized DNA was eluted in $0.14 \mathrm{M} \mathrm{PB}+$ $0.4 \%$ sodium dodecyl sulfate by use of a batch procedure (3). Reassociated DNA is adsorbed to HA. It is eluted at higher salt $(0.4 \mathrm{M} \mathrm{PB})$ or in a series of $0.14 \mathrm{M} \mathrm{PB}$ washes at increasing $5 \mathrm{C}$ increments. The latter procedure yields a thermal elution profile, since duplexed DNA fragments elute when the temperature is high enough to denature them.

\section{RESULTS AND DISCUSSION}

Members of $E$. tarda are gram-negative, peritrichous, rod-shaped bacteria that conform to the biochemical definition of Enterobacteriaceae. They exhibit a large number of serotypes based on their $\mathrm{O}$ and $\mathrm{H}$ antigens, but are quite uniform in their biochemical reactions $(9,11)$. They seem to resemble $E$. coli in

TABLE 3. Reassociation of DNA from Edwardsiella tarda 3592-64

\begin{tabular}{|c|c|c|c|}
\hline Source of unlabeled DNA & $\begin{array}{c}\text { Relative (\%) } \\
\text { binding, } 60 \mathrm{C}\end{array}$ & $\underset{60 \mathrm{C}}{\text { Divergence }(\%),{ }^{a}}$ & $\begin{array}{c}\text { Relative }(\%) \\
\text { binding, } 75 \mathrm{C}\end{array}$ \\
\hline Edwardsiella tarda 3592-64 & 100 & NT & 100 \\
\hline E. tarda $5343-61$ & 85 & 1.1 & 84 \\
\hline E. tarda $3979-60$ & 90 & 0.6 & 88 \\
\hline E. tarda $3889-64$ & 93 & 0.8 & 93 \\
\hline E. tarda $1126-64$ & 86 & 2.8 & 86 \\
\hline E. tarda $6243-61$ & 95 & 0.3 & NT \\
\hline E. tarda $1795-62$ & 84 & +0.3 & 82 \\
\hline E. tarda $3888-64$ & 88 & 4.8 & NT \\
\hline E. tarda $3882-61$ & 93 & 2.1 & NT \\
\hline E. tarda 2334-67 & 84 & 3.9 & 81 \\
\hline E. tarda $5159-63$ & 86 & +0.5 & NT \\
\hline E. tarda $1483-59$ & 91 & +0.1 & NT \\
\hline E. tarda $2995-65$ & 82 & 0.5 & 84 \\
\hline E. tarda $4226-59$ & 87 & 1.2 & NT \\
\hline E. tarda $4862-60$ & 87 & 0.7 & NT \\
\hline E. tarda $5497-61$ & 85 & 0.5 & 84 \\
\hline E. tarda $4411-68$ & 86 & 0.1 & NT \\
\hline E. tarda $4751-66$ & 88 & 0.8 & NT \\
\hline E. tarda $4830-60$ & 96 & 2.4 & 90 \\
\hline E. tarda 3893-64 & 89 & NT & 92 \\
\hline Escherichia coli $\mathrm{K}-12$ & 25 & NT & 7 \\
\hline Salmonella typhimurium LT2 & 25 & NT & 7 \\
\hline S. phoenix & 25 & NT & NT \\
\hline Arizona hinshawii 1 & 25 & NT & NT \\
\hline A. hinshawii 62 & 25 & NT & NT \\
\hline Citrobacter freundii $460-61$ & 22 & NT & 7 \\
\hline Serratia marcescens $868-57$ & 28 & NT & 11 \\
\hline Citrobacter freundii lysine $+4556-71$ & 28 & NT & NT \\
\hline Serratia liquefaciens $446-68$ & 25 & NT & NT \\
\hline Serratia rubidaea $934-72$ & 25 & NT & NT \\
\hline Enterobacter aerogenes $1627-66$ & 26 & NT & 8 \\
\hline Enterobacter cloacae 1347-71 & 25 & NT & NT \\
\hline Enterobacter cloacae 2564 & 23 & NT & NT \\
\hline Enterobacter agglomerans $\mathrm{EH} 103$ & 24 & NT & NT \\
\hline Enterobacter hafniae & 29 & NT & 7 \\
\hline Klebsiella rhinoscleromatis $895-68$ & 24 & NT & NT \\
\hline Erwinia nimipressuralis EN1 & 25 & NT & NT \\
\hline Erwinia amylovora EA178 & 22 & NT & 7 \\
\hline Erwinia nigrifluens EN101 & 25 & NT & NT \\
\hline Pectobacterium carotovorum 495 & 20 & NT & 5 \\
\hline Pectobacterium cypripedii EC155 & 22 & NT & NT \\
\hline Pectobacterium carnegieana EC186 & 21 & NT & NT \\
\hline Proteus morganii & 16 & NT & NT \\
\hline Proteus mirabilis & 8 & NT & \T \\
\hline
\end{tabular}

${ }^{a}$ See Table 2. NT, Not tested. 
certain reactions, but many biochemical characteristics differ in E. tarda and E. coli. There seems to be complete acceptance of their placement as one species in a separate genus and tribe of Enterobacteriaceae.

The indole, methyl red, Voges-Proskauer, and citrate reactions of $E$. tarda are similar to those exhibited by $E$. coli (8). For this reason, DNA from strains of $E$. tarda was reacted with labeled DNA from $E$. coli K-12. Optimal relatedness between $E$. coli and strains of $E$. tarda is approximately 20\% (Table 2). The related sequences contain about $14 \%$ unpaired nucleotide bases. When reactions are carried out at $75 \mathrm{C}$, where only highly related sequences can reassociate, relatedness falls to less than $5 \%$. Thus, $E$. tarda is significantly less related to $E$. coli than are representatives of Shigella, Salmonella, Citrobacter, Klebsiella, and Enterobacter cloacae. Serratia marcescens, Enterobacter hafniae, and Proteus morganii are related to $E$. coli at a level similar to that shown by $E$. tarda. Only Proteus mirabilis shows less relatedness to $E$. coli than does $E$. tarda.

Relatedness in a diverse assortment of $E$. tarda strains was determined in reactions using labeled DNA from $E$. tarda 3592-64 (Table 3). The average relatedness of $E$. tarda strains in $60-\mathrm{C}$ reactions is $88 \%$. There is evidence of only about $1 \%$ average divergence in related sequences. Conservation of $E$. tarda is also obvious from 75-C reactions, where average relatedness is $86 \%$. Representatives of established genera from the tribes Escherichieae, Salmonelleae, and Klebsielleae exhibit 20 to $29 \%$ relatedness to $E$. tarda 3592-64. An approximate threefold decrease in duplex formation is observed in 75-C reactions. Relatedness of $E$. tarda to $P$. morganii and $P$. mirabilis at $60 \mathrm{C}$ is 16 and $8 \%$, respectively.

These data leave little doubt that the strains of $E$. tarda examined thus far are extremely similar in overall polynucleotide base sequence. Furthermore, E. tarda exhibits only 20 to $25 \%$ relatedness to most members of all other genera. As pointed out in previous studies (1), most members of Enterobacteriaceae exhibit a minimum of about $20 \%$ relatedness. That $E$. tarda shows no more than this core level of relatedness to other enteric bacteria is consistent with its classification as a single genus in a separate tribe.

All 20 strains of E. tarda studied are highly interrelated. This sample includes the type strain, 1483-59, the Bartholomew group isolate, 1795-62, and five of the Asakusa group strains. The strains were isolated from clinical and nonclinical human sources, as well as from invertebrates from 11 states and five widely separated countries. Furthermore, these strains contain 19 different $O$ antigens and 11 different $\mathrm{H}$ antigens. Thus, the single species designation seems valid for all strains of $E$. tarda thus far isolated.

\section{ACKNOWLEDGMENT}

We are indebted to William J. Martin for his kindness in selecting and providing the wide variety of Edwardsiella tarda strains used in this study.

\section{REPRINT REQUESTS}

Address reprint requests to: Dr. Don J. Brenner, Division of Biochemistry, Walter Reed Army Institute of Research, Washington, D.C. 20012.

\section{LITERATURE CITED}

1. Brenner, D. J., G. R. Fanning, K. E. Johnson, R. V. Citarella, and S. Falkow. 1969. Polynucleotide sequence relationships among members of the Enterobacteriaceae. J. Bacteriol. 98:637-650.

2. Brenner, D. J., G. R. Fanning, A. Rake, and K. E. Johnson. 1969. A batch procedure for thermal elution of DNA from hydroxyapatite. Anal. Biochem. 28:447-459.

3. Brenner, D. J., A. G. Steigerwalt, G. V. Miklos, and G. R. Fanning. 1973. Deoxyribonucleic acid relatedness among erwiniae and other Enterobacteriaceae: the soft-rot organisms (genus Pectobacterium Waldee). Int. J. Syst. Bacteriol. 23:205-216.

4. Britten, R. J., and D. E. Kohne. 1966. Nucleotide sequence repetition in DNA. Carnegie Inst. Wash. Yearb. 65:78-106.

5. Crosa, J. H., D. J. Brenner, W. H. Ewing, and S. Falkow. 1973. Molecular relationships among the Salmonelleae. J. Bacteriol. 115:307-315.

6. D'Empaire, M. 1969. Les facteurs de croissance des Edwardsiella tarda. Ann. Inst. Pasteur (Paris) 116:63-68

7. Ewing, W. H., A. C. McWhorter, M. M. Ball, and S. F. Bartes. 1969. Edwardsiella tarda: biochemical reaction. J. Conf. Pub. Health Lab. Dir. 27:129-141.

8. Ewing, W. H., A. C. McWhorter, M. R. Escobar, and A. H. Lubin. 1965. Edwardsiella, a new genus of Enterobacteriaceae based on a new species, $E$. tarda. Int. Bull. Bacteriol. Nomen. Taxon. 15:33-38.

9. King, B. M., and D. L. Adler. 1964. A previously undescribed group of Enterobacteriaceae. Amer. J. Clin. Pathol. 41:230-232.

10. Laird, C. D., B. L. McConaughy, and B. J. McCarthy. 1969. On the rate of fixation of 
nucleotide substitutions in evolution. Nature (London) 224:149-154.

11. Sakazaki, $\cdot$ R. 1965. A proposed group of the family Enterobacteriaceae, the Asakusa group. Int. Bull. Bacteriol. Nomen. Taxon. 15:45-47.
12. Sonnenwirth, A. C. 1970. Bacteremia with and without meningitis due to Yersinia enterocolitica, Edwardsiella tarda, Comamonas terrigena and Pseudomonas maltophilia. Ann. N.Y. Acad. Sci. 174:488-502. 